\title{
Variation of yield, milling, technological and rheological characteristics in some Egyptian bread wheat (Triticum aestivum L.) cultivars
}

\author{
M. F. Seleiman ${ }^{1,4 *}$, S. M. Abdel-Aal' ${ }^{2}$, M. E. Ibrahim ${ }^{2}$ and P. Monneveux ${ }^{3}$ \\ ${ }^{1}$ Department of Agricultural Sciences, P. O. Box 27, FI-00014, University of Helsinki, \\ Finland; ${ }^{2}$ Department of Crop Science, Faculty of Agriculture, Minufiya University, Egypt; \\ ${ }^{3}$ Montpellier SupAgro 2, Place Pierre Viala 34060 Montpellier Cedex 01, France
}

\begin{abstract}
A field experiment was conducted to evaluate yield, milling, technological and rheological characteristics of four Egyptian bread wheat cultivars (Gemmeiza 7, Gemmeiza 9, Sakha 93 and Giza 168). Results showed that Gemmeiza 9 had the highest number of spikes per $\mathrm{m}^{2}$, number of grains per spike and grain yield. Gemmeiza 7 had the highest fine and coarse bran, protein, wet and dry gluten percentages as well as the best farinograph and extensograph properties (dough development time, dough stability time and dough resistance to extension). Sakha 93 had higher flour and carbohydrate percentages than the other cultivars. Consequences for breeding are discussed.
\end{abstract}

Key words: wheat, Triticum aestivum L., yield, grain quality, rheological properties, dough.
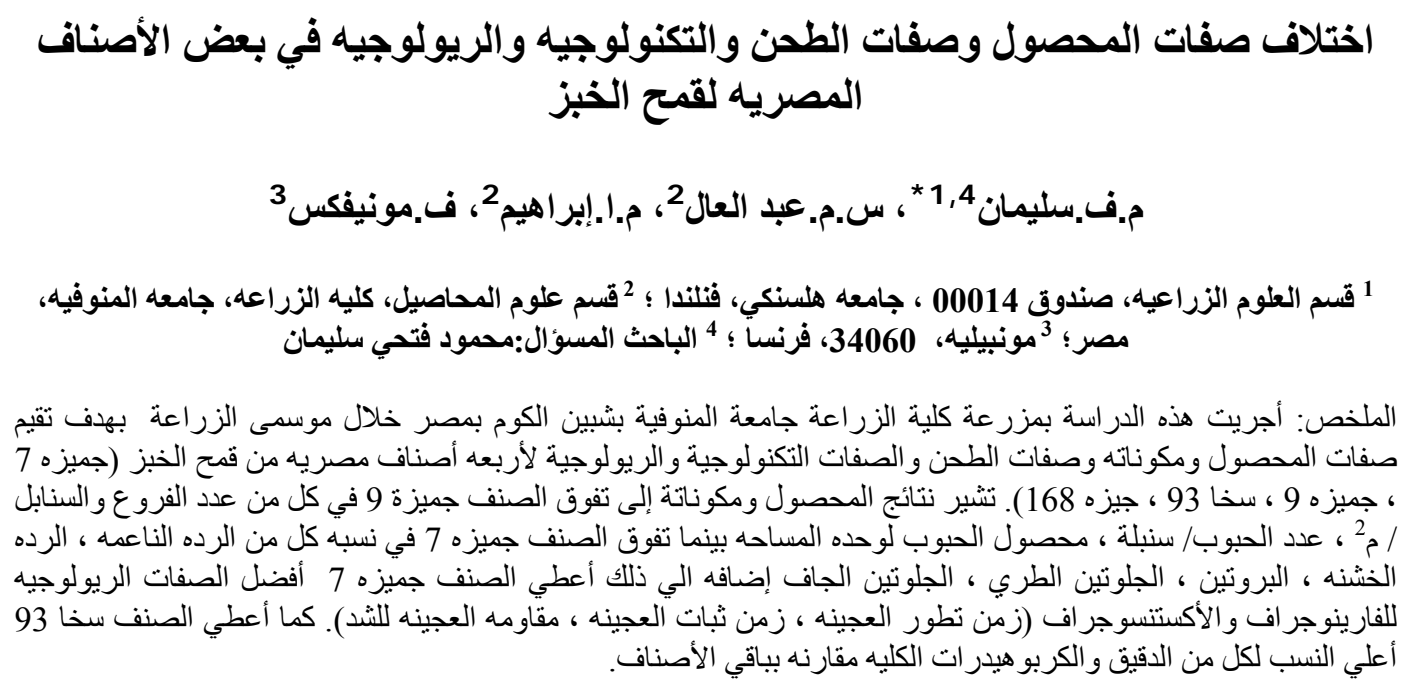

\section{Introduction}

Raising bread wheat (Triticum aestivum L.) production is an important national target in Egypt, in order to minimize the gap between wheat production and consumption. Wheat production and yield have increased between 1985 and 2003 from 1.87 to 6.15 million tons and from 3.76 to $6.15 \mathrm{t} \mathrm{ha}^{-1}$, respectively (FAO, 2009), indicating that production enhancement was largely obtained from yield increase (Ahmed et al., 2006). More attention was given in breeding to grain yield and its components rather than quality of grains, flour and dough, in spite of the importance of these properties to obtain a good product. Morever, yield increase is often obtained in detriment of grain quality. For example, Gemmeiza 9 was reported by Mahrous and Abd-Elhady (2006) to have the highest grain yield and farinograph properties (dough development period and dough stability period) while Gemmeiza 7 produced the highest values of grain 
protein, wet and dry gluten percentages and farinograph property (water absorption percentage).

Gluten content is an important factor in assessing flour quality (Kulkarni et al., 1987). Gluten is a plastic-elastic protein fraction of wheat flour responsible for physical dough properties. It has been generally accepted that any increase in total protein content of the flour results in an increase of gluten content (Perten et al., 1992). Farinograph is the most important and widely used instrument to test the quality and strength of the flour by determining parameters such as, water absorption of flour, dough development time, dough stability and weakness.

The present investigation was consequently carried out to evaluate the variation in productivity, milling, quality and rheological characteristics of four Egyptian bread wheat cultivars (Gemmeiza 7, Gemmeiza 9, Sakha 93 and Giza 168) during two growing seasons. Technological and rheological characteristics were assessed by estimating gluten content and farinograph parameters, respectively.

\section{Materials and methods}

\section{Experimental conditions}

The present investigation was conducted at the Experimental Farm, Faculty of Agriculture, Minufiya University, Egypt, during the growing seasons of 2004/2005 and 2005/2006 (hereafter referred as season 1 and 2). Main soil characteristics are given by Table 1. Rainfall was low during the vegetative period (42 and $30 \mathrm{~mm}$ in seasons 1 and 2, respectively), and zero during the reproductive period. Average maximal temperature during grain filling was around $32.5^{\circ} \mathrm{C}$.

Table 1. Soil characteristics of the experimental field soil in both seasons.

\begin{tabular}{llllllllll}
\hline & $\begin{array}{l}\text { Fine } \\
\text { sand } \\
\text { \% }\end{array}$ & $\begin{array}{l}\text { Coarse } \\
\text { sand } \\
\text { \% }\end{array}$ & $\begin{array}{l}\text { Silt } \\
\text { \% }\end{array}$ & $\begin{array}{l}\text { Clay } \\
\text { \% }\end{array}$ & pH & $\begin{array}{l}\text { Organic } \\
\text { matter } \\
\text { \% }\end{array}$ & $\begin{array}{l}\text { N } \\
\text { ppm }\end{array}$ & $\begin{array}{l}\text { P } \\
\text { ppm }\end{array}$ & $\begin{array}{l}\text { K } \\
\text { ppm }\end{array}$ \\
\hline Season 1 & 22.2 & 13.7 & 28.7 & 35.4 & 7.8 & 2.0 & 25.0 & 7.6 & 414.4 \\
Season 2 & 25.7 & 6.2 & 36.0 & 32.1 & 7.9 & 1.8 & 30.0 & 6.5 & 351.2 \\
\hline
\end{tabular}

The experiment included four bread wheat cultivars (Triticum aestivum L., cultivars Gemmeiza 7, Gemmeiza 9, Sakha 93 and Giza 168). The genotypes were arranged in a randomized complete block design with four replications. The area of each experimental plot was $12 \mathrm{~m}^{2}$. Sowing was done on $15^{\text {th }}$ November in both seasons. Grains were hand drilled in fifteen rows 20 $\mathrm{cm}$ apart at a rate of $143 \mathrm{~kg}$ grains/ha. The plants were irrigated six times and the irrigation was held three weeks before harvesting. Nitrogen fertilization was applied at a rate of $143 \mathrm{~kg} \mathrm{~N} \mathrm{ha}^{-1}$ as urea $(46.5 \%)$ in two equal doses before the first and second irrigations. Calcium super phosphate $(15.5 \%$ $\mathrm{P}_{2} \mathrm{O}_{5}$ ) was applied during soil preparation at the rate of $37 \mathrm{~kg} \mathrm{P}_{2} \mathrm{O}_{5} \mathrm{ha}^{-1}$. The preceding crop was maize in both seasons.

\section{Measurements}

At maturity, number of spikes $\mathrm{m}^{-2}$, number of grains per spike and grain weight per spike were determined on one square meter taken randomly from the middle area of each plot. Grain and biological yield $\left(\mathrm{t} \mathrm{ha}^{-1}\right)$ were assessed from the whole plot area.

Milling characteristics (flour percentage, fine and coarse bran concentrations) were measured after grain milling according to AACC (2000). Crude protein percentage was obtained by multiplying grain nitrogen content by 5.7 according to the method described by AACC 
(2000). Nitrogen percentage in the grains was determined using micro Kjeldahl method as described by Peter and Young (1980). Total carbohydrate percentage in the grains was determined according to the method of Dubois et al. (1956). Ash, wet and dry gluten percentages were measured according to AACC (2000). Wet gluten was obtained by forming dough by adding $15 \mathrm{ml}$ of water to $25 \mathrm{~g}$ of flour. The dough was kept in a beaker for one hour, repeatedly washed manually until all starch was released, and weighed. Dry gluten was obtained after oven-drying the dough at $105^{\circ} \mathrm{C}$.

Dough obtained from grain of the different genotypes were analysed at the Food Technology Research Institute, Agricultural Research Center, Giza, Egypt. It was analyzed for each treatment by pooling flour samples from the four replications. Water absorption of the dough (\%), dough development time ( $\mathrm{min})$, dough stability time (min) and dough weakness (Brabender Units, BU) were estimated in both years using a farinograph $(\mathrm{Nr}$ 941020, type 8I0105001, Brabender GmbH and Co. KG, Duisburg, Germany). Water absorption was estimated as the percentage of water in the dough for reaching strength of 500 BU. Dough development time was the time in minutes elapsing from the first addition of water to the development of dough maximum consistency. Dough stability time was the time in minutes between the dough development time and breakdown of the curve (i.e. the time elapsing after the mixing curve intersected the $500 \mathrm{BU}$ lines until it left it). Dough weakness was the drop in consistency (BU) during the first $12 \mathrm{~min}$ of breakdown. In season 2 , dough resistance to extension and extensibility were determined using a Brabender Extensograph apparatus (Nr. 946003 type 860001, Brabender GmbH and Co. KG, Duisburg, Germany). Dough resistance to extension (R) was obtained from the maximum height of the curve in
Brabender units (BU). Dough extensibility (E) was estimated by the total length of curve, in mm. A proportional number was calculated by divided dough resistance by dough extensibility $(\mathrm{R} / \mathrm{E})$.

Data obtained was analyzed using SPSS, version 10 (SPSS, 1999). Mean of values were compared at 5\% level of probability using Duncan's multiple range test (Duncan, 1955).

\section{Results and discussion}

Significant differences were detected among the four tested cultivars for yield components (Table 2). High variation for yield components was also found among Egyptian wheat cultivars (Ibrahim and Abdel-Aal, 1991; Ali et al., 2004; Gafaar, 2007). In both seasons, Gemmeiza 9 had the highest number of spikes $\mathrm{m}^{-2}$, number of grains per spike, grain weight per spike and grain yield. Gemmeiza 9 was also reported by Mahrous and Abd-Elhady (2006) as the most productive Egyptian cultivar. Gemmeiza 7 had the highest biomass and Sakha 93 the lowest. Abdel-Hmeed (2005) also found that Giza 168 had higher biomass than Sakha 93. Giza 168 had the lowest number of spikes $\mathrm{m}^{-2}$ and grain yield.

The tested four wheat cultivars also significantly differed for milling characteristics, i.e. flour, fine and coarse bran percentages (Table 3 ), as already reported by Toaima et al. (2000) and El-Nagar (2003). In both seasons, Sakha 93 had the highest flour percentage and the lowest fine and coarse bran percentages, as compared with the other tested cultivars. Similarly, Mahrous and Abd-Elhady (2006) reported that Sakha 93 had higher flour percentage than other Egyptian wheat cultivars like Sids 1, Gemmeiza 9, Giza 168, Gemmeiza 7, Sakha 94 and Gemmeiza 10. Conversely, Gemmeiza 7 had the lowest flour percentage and the highest fine and coarse bran percentages. Gemmeiza 9 and Giza 168 had intermediate values. 
Table 2. Grain yield and its components of the tested cultivars in both seasons.

\begin{tabular}{|c|c|c|c|c|c|}
\hline Cultivars & $\begin{array}{l}\text { Number of } \\
\text { spikes } \mathbf{m}^{-2}\end{array}$ & $\begin{array}{l}\text { Number of } \\
\text { grains per spike }\end{array}$ & $\begin{array}{l}\text { Grain } \\
\text { weight per } \\
\text { spike }(\mathrm{g})\end{array}$ & $\begin{array}{l}\text { Grain yield } \\
\left(\mathrm{t} \mathrm{ha}^{-1}\right)\end{array}$ & $\begin{array}{l}\text { Biomass } \\
\left(\mathrm{t} \mathrm{ha}^{-1}\right)\end{array}$ \\
\hline \multicolumn{6}{|c|}{ Season 1} \\
\hline Gemmeiza 7 & $344.2^{\mathrm{b}}$ & $69.3^{\mathrm{b}}$ & $3.00^{\mathrm{a}}$ & $6.92^{\mathrm{b}}$ & $19.83^{\mathrm{a}}$ \\
\hline Gemmeiza 9 & $355.7^{\mathrm{a}}$ & $75.8^{\mathrm{a}}$ & $3.03^{\mathrm{a}}$ & $7.11^{\mathrm{a}}$ & $19.15^{\mathrm{c}}$ \\
\hline Sakha 93 & $338.0^{\mathrm{c}}$ & $60.0^{\mathrm{c}}$ & $2.91^{\mathrm{b}}$ & $6.81^{\mathrm{c}}$ & $17.65^{\mathrm{d}}$ \\
\hline Giza 168 & $324.2^{\mathrm{d}}$ & $60.0^{\mathrm{c}}$ & $2.80^{\mathrm{c}}$ & $6.66^{\mathrm{d}}$ & $19.65^{\mathrm{b}}$ \\
\hline \multicolumn{6}{|c|}{ Season 2} \\
\hline Gemmeiza 7 & $346.2^{b}$ & $69.4^{b}$ & $3.02^{\mathrm{a}}$ & $6.99^{\mathrm{b}}$ & $19.97^{\mathrm{a}}$ \\
\hline Gemmeiza 9 & $359.5^{\mathrm{a}}$ & $74.3^{\mathrm{a}}$ & $3.06^{\mathrm{a}}$ & $7.14^{\mathrm{a}}$ & $19.42^{\mathrm{c}}$ \\
\hline Sakha 93 & $340.0^{\mathrm{c}}$ & $60.0^{c}$ & $2.93^{b}$ & $6.85^{\mathrm{c}}$ & $17.75^{\mathrm{d}}$ \\
\hline Giza 168 & $326.7^{\mathrm{d}}$ & $62.7^{\mathrm{c}}$ & $2.82^{\mathrm{c}}$ & $6.70^{\mathrm{d}}$ & $19.79^{\mathrm{b}}$ \\
\hline
\end{tabular}

Mean values in the same column without a common letter are significantly different $(\mathrm{P}<0.05)$ according to the Duncan's comparison test.

A high variation was found among Egyptian wheat cultivars for ash content and total carbohydrate percentages (Toaima et al., 2000; Abd El-Razik, 2005). In the present study, Gemmeiza 7 had the lowest ash content and total carbohydrate percentage as well as the highest protein, wet and dry gluten percentages (Table 4). This result is in good agreement with Mahrous and Abd-Elhady (2006) who also found high values of protein, wet and dry gluten percentages in Gemmeiza 7. Giza 168, Gemmeiza 9 and Sakha 93 ranked in a decreasing order for protein content. Giza 168 and Gemmeiza 9 had the highest gluten percentages and Sakha 93 the lowest. Giza 168 and Gemmeiza 9 also had the highest ash content while Gemmeiza 9 and Sakha 93 had the highest carbohydrates content.

Table 3. Milling characteristics of the tested cultivars in both seasons.

\begin{tabular}{lcccccc}
\hline \multirow{2}{*}{ Cultivars } & \multicolumn{2}{c}{ Flour \% } & \multicolumn{2}{c}{ Fine bran \% } & \multicolumn{2}{c}{ Coarse bran \% } \\
\cline { 2 - 7 } & Season 1 & Season 2 & Season 1 & Season 2 & Season 1 & Season 2 \\
\hline Gemmeiza 7 & $69.6^{\mathrm{d}}$ & $70.1^{\mathrm{d}}$ & $9.4^{\mathrm{a}}$ & $9.5^{\mathrm{a}}$ & $21.1^{\mathrm{a}}$ & $20.5^{\mathrm{a}}$ \\
Gemmeiza 9 & $72.9^{\mathrm{b}}$ & $73.0^{\mathrm{b}}$ & $7.7^{\mathrm{c}}$ & $7.8^{\mathrm{c}}$ & $19.4^{\mathrm{c}}$ & $19.3^{\mathrm{c}}$ \\
Sakha 93 & $73.5^{\mathrm{a}}$ & $73.8^{\mathrm{a}}$ & $7.5^{\mathrm{d}}$ & $7.6^{\mathrm{d}}$ & $19.0^{\mathrm{d}}$ & $18.7^{\mathrm{d}}$ \\
Giza 168 & $70.8^{\mathrm{c}}$ & $71.0^{\mathrm{c}}$ & $8.8^{\mathrm{b}}$ & $8.9^{\mathrm{b}}$ & $20.5^{\mathrm{b}}$ & $20.1^{\mathrm{b}}$ \\
\hline
\end{tabular}

Mean values in the same column without a common letter are significantly different $(\mathrm{P}<0.05)$ according to the Duncan's comparison test.

The highest values for water absorption percentage, dough development and dough stability times were obtained by Gemmeiza 7 followed by Giza 168, Gemmeiza 9 and Sakha 93 in a decreasing order (Table 5 and Figure 1). Mahrous and Abd- Elhady (2006) also reported a high value of water absorption percentage in
Gemmeiza 7. Sakha 93 had the highest value for dough weakness. These results may be attributed to the highest values of protein and wet and dry gluten percentages of Gemmeiza 7 which caused an increase in its water absorption percentage, dough development and dough stability times compared to the other tested cultivars. 
Table 4. Grain composition of the tested cultivars in both seasons.

\begin{tabular}{|c|c|c|c|c|c|c|c|c|c|c|}
\hline \multirow[t]{2}{*}{ Cultivars } & \multicolumn{2}{|c|}{ Protein \% } & \multicolumn{2}{|c|}{ Wet gluten \% } & \multicolumn{2}{|c|}{ Dry gluten \% } & \multicolumn{2}{|c|}{ Ash \% } & \multicolumn{2}{|c|}{$\begin{array}{l}\text { Total } \\
\text { carbohydrate } \\
(\%)\end{array}$} \\
\hline & $\overline{S-1}$ & S-2 & S-1 & S- 2 & S-1 & $\mathrm{S}-2$ & S-1 & S-2 & S- 1 & $\mathrm{~S}-2$ \\
\hline Gemmeiza 7 & $13.2^{\mathrm{a}}$ & $13.6^{\mathrm{a}}$ & $31.3^{\mathrm{a}}$ & $31.8^{\mathrm{a}}$ & $13.1^{\mathrm{a}}$ & $13.2^{\mathrm{a}}$ & $1.27^{\mathrm{d}}$ & $1.28^{\mathrm{d}}$ & $67.1^{\mathrm{d}}$ & $68.0^{c}$ \\
\hline Gemmeiza 9 & $12.8^{\mathrm{c}}$ & $12.9^{\mathrm{c}}$ & $24.3^{\mathrm{b}}$ & $25.3^{\mathrm{b}}$ & $11.3^{\mathrm{b}}$ & $11.6^{\mathrm{b}}$ & $1.79^{\mathrm{b}}$ & $1.80^{\mathrm{b}}$ & $70.9^{\mathrm{b}}$ & $71.7^{\mathrm{b}}$ \\
\hline Sakha 93 & $11.7^{\mathrm{d}}$ & $11.7^{\mathrm{d}}$ & $21.2^{\mathrm{c}}$ & $23.4^{\mathrm{c}}$ & $10.3^{\mathrm{c}}$ & $11.1^{\mathrm{c}}$ & $1.49^{\mathrm{c}}$ & $1.51^{\mathrm{c}}$ & $72.8^{\mathrm{a}}$ & $73.3^{\circ}$ \\
\hline Giza 168 & $13.2^{\mathrm{b}}$ & $13.2^{\mathrm{b}}$ & $30.5^{\mathrm{a}}$ & $31.0^{\mathrm{a}}$ & $12.9^{\mathrm{a}}$ & $13.2^{\mathrm{a}}$ & $1.89^{\mathrm{a}}$ & $1.92^{\mathrm{a}}$ & $68.4^{\mathrm{c}}$ & $68.8^{\mathrm{c}}$ \\
\hline
\end{tabular}

Mean values in the same column without a common letter are significantly different $(\mathrm{P}<0.05)$ according to the Duncan's comparison test. S-1 \& S-2 denotes Season 1 and Season 2 respectively.

Table 5. Rheological properties (Farinograph) of the tested cultivars in both seasons.

\begin{tabular}{lllllllll}
\hline \multirow{2}{*}{ Cultivars } & \multicolumn{2}{l}{$\begin{array}{l}\text { Water absorption } \\
\text { (\%) }\end{array}$} & \multicolumn{2}{l}{$\begin{array}{l}\text { Dough development } \\
\text { time (min) }\end{array}$} & \multicolumn{2}{l}{$\begin{array}{l}\text { Dough stability } \\
\text { time (min) }\end{array}$} & \multicolumn{2}{l}{$\begin{array}{l}\text { Dough } \\
\text { weakness (BU) }\end{array}$} \\
\cline { 2 - 9 } & S-1 & S-2 & S-1 & S-2 & S-1 & S-2 & S-1 & S-2 \\
\hline Gemmeiza 7 & 65.5 & 66.5 & 3.00 & 3.50 & 6.00 & 6.00 & 20 & 20 \\
Gemmeiza 9 & 63.0 & 63.5 & 1.50 & 2.00 & 1.50 & 3.50 & 120 & 100 \\
Sakha 93 & 59.3 & 61.6 & 1.00 & 1.50 & 2.00 & 2.00 & 160 & 140 \\
Giza 168 & 63.7 & 64.4 & 2.50 & 2.50 & 5.00 & 5.50 & 60 & 57 \\
\hline
\end{tabular}
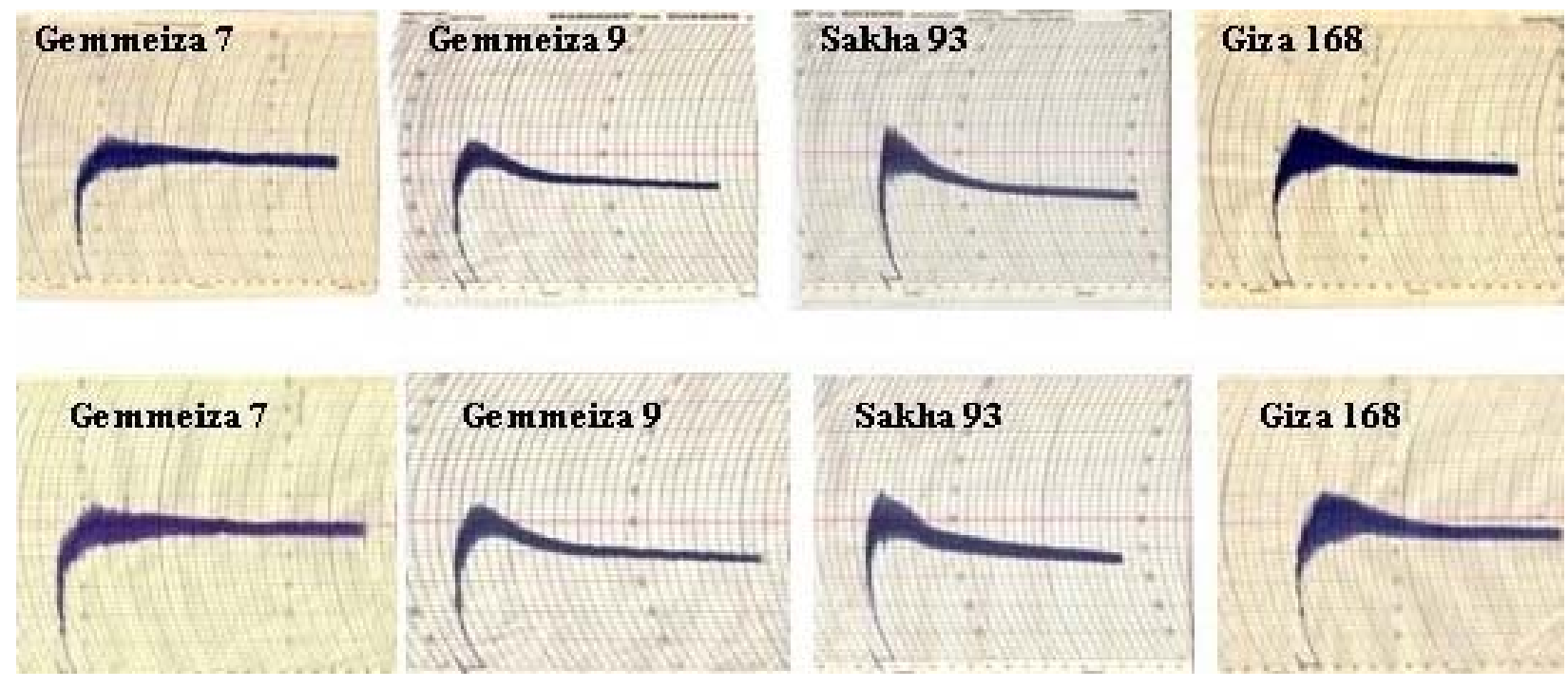

Figure 1. Variation in rheological properties (Farinograph) of dough between different wheat cultivars in both seasons (above: season 1; below, season 2). 
Extensograph characteristics are shown in Table 6 and Figure 2. The maximum dough resistance to extension (BU) was obtained with Gemmeiza 7 while the maximum dough extensibility $(\mathrm{mm})$ was obtained with Gemmeiza 9. Sakha 93 had the lowest dough resistance to extension as compared with the other tested wheat cultivars. The highest proportional number was noted for Gemmeiza 7 indicating a balance of gluten characteristic and dough quality in this cultivar. Similar results were obtained by Mahrous and Abd-Elhady (2006).

Table 6. Rheological properties (Extensograph) of the tested cultivars in both seasons.

\begin{tabular}{llll}
\hline Cultivars & $\begin{array}{l}\text { Dough resistance to } \\
\text { extension (BU) }\end{array}$ & $\begin{array}{l}\text { Dough extensibility } \\
\text { (mm) }\end{array}$ & $\begin{array}{l}\text { Proportional } \\
\text { number (R/E) }\end{array}$ \\
\hline Gemmeiza 7 & 610 & 60 & 10.16 \\
Gemmeiza 9 & 340 & 155 & 2.19 \\
Sakha 93 & 300 & 53 & 5.66 \\
Giza 168 & 460 & 64 & 7.18 \\
\hline
\end{tabular}

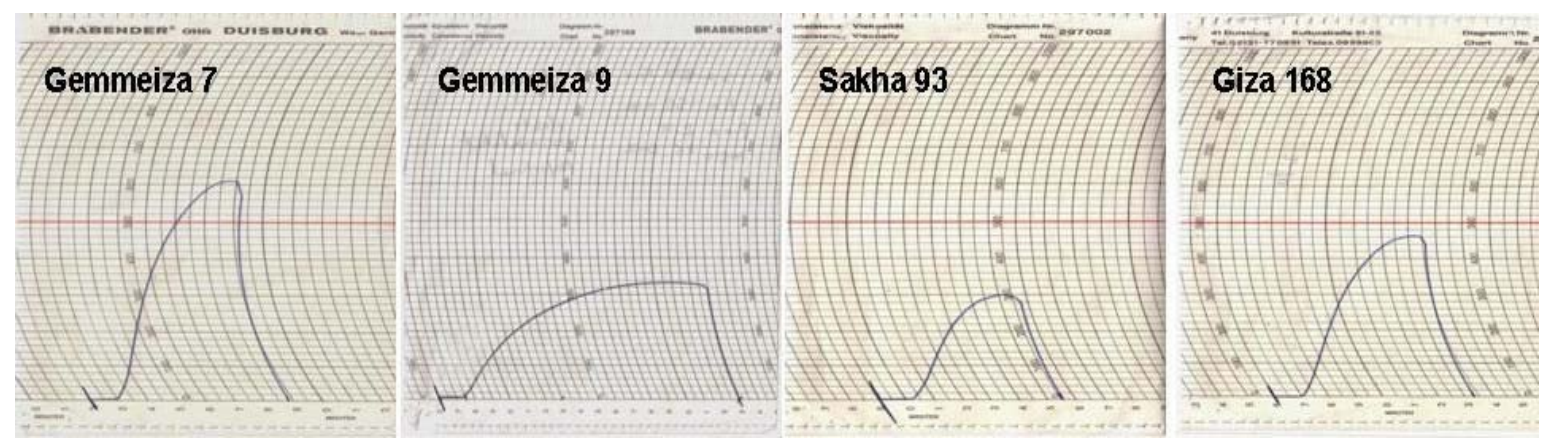

Figure 2. Variation in rheological properties (Extensograph) of dough between different wheat cultivars.

\section{Conclusion}

In summary, Gemmeiza 9 gave the highest yield and its components. However, the highest values of protein and related traits (wet and dry gluten percentages) as well as dough development time, dough stability time and resistance to extension were obtained from Gemmeiza 7. On the other hand, Sakha 93 gave highest flour and carbohydrate percentages. Further breeding activities should be based on crosses between Gemmeiza 9, Gemmeiza 7 and Giza 168 for improving milling, technological and rheological characteristics. Also, crossing among these cultivar and Sakha 93 could serve breeding lines for obtaining a good compromise between grain yield and quality. The results obtained during this work were collected from other geographic region than the results obtained by several cited authors

\section{Acknowledgment}

We are deeply indebted to Prof. Pirjo Makela, Professor of Crop Science, Department of Agricultural Sciences, University of Helsinki, Finland, for her guidance and advices.

\section{References}

A. A. C. C. 2000. American Association of Cereal Chemists. Cereal Laboratory Methods. St. Paul., Minnesota, USA.

Abd-El-Razik, M. A. 2005. Morphological and technological studies on some 
wheat varieties. J. Agric. Sci. Mansoura Univ. 30:4407-4417.

Abdel-Hmeed, I. M. 2005. Response of two newly released bread wheat cultivars to different nitrogen and phosphorus fertilizer levels. Alex. J. Agric. Res. 50:63-77.

Ahmed, G., M. S. Hassanein and M. M. El-Gazzar. 2006. Growth and yield response of two wheat cultivars to complete foliar fertilizer compound "Dogoplus". J. App. Sci. Res. 2:2026.

Ali, A. G. A., O. E. Zeiton, A. H. Bassiauny and A. R. Y. A. ElBanna. 2004. Productivity of wheat cultivars grown at El- Khattara and El-Arish under different levels of planting densities and Nfertilization. Zagazig J. Agric. Res. 31: $1225-1256$.

Dubois, M., K. A. Gilles, J. K. Hamilton, P. A. Robers and F. Smith. 1956. Colorimetric method for determination of sugar and related substances. Anal. Chem. 28:350356.

Duncan, D. B. 1955. Multiple range and multiple F. Test. Biometrics 11:1-42.

El-Nagar, G. R. 2003. Yield and quality of some spring wheat genotypes subjected to different nitrogen fertilizer rates. Assiut J. Agric. Sci. 34:43-63.

F. A. O. 2009. www.Fao.org/ag/AGP /AGPC/doc/field/wheat/africa/egypt/ egyptagec.htm.
Gafaar, N. A. 2007. Response of some bread wheat varieties grown under different levels of planting density and nitrogen fertilizer. Minufiya $\mathrm{J}$. Agric. Res. 32:165-183.

Ibrahim, M. E. and S. M. Abdel-Aal. 1991. Influence of nitrogen, phosphorus and potassium fertilization on growth, yield and protein content of some wheat varieties. Minufiya J. Agric. Res. 16:191-205.

Kulkarni, R. G., J. G. Ponte and K. Kulp. 1987. Significance of gluten content as an index of flour quality. Cereal Chem. 64:1-3.

Mahrous, M. A. and Y. A. Abd-Elhady. 2006. Studies of quality and baking traits in bread wheat. Minufiya J. Agric. Res. 31:899-914.

Perten H., K. Bondesson and A. Mjorndal. 1992. Cereal Foods World 37:655660.

Peter, L. P. and V. R. Young. 1980. Nutritional Evaluation of Protein Foods. The United Nations University, Japan. P 8.

SPSS. 1999. Statistical Package for Social Science program version 10 .

Toaima, S. E. A, A. A. El-Hofi and H. Ashoush. 2000. Yield and technological characteristics of some wheat varieties as affected by $\mathrm{N}$ fertilization and seed rates. J. Agric. Sci. Mansoura Univ. 25:2449-2467. 